\title{
A Novel, Simple and Green Capillary Electrophoresis Determination of Sertraline in Pharmaceutical Dosage Forms
}

\author{
Sertralin'in Farmasötik Dozaj Formlarında Yeni, Basit, Çevreci \\ Kapiler Elektroforez ile Tayini
}

\author{
Research Article \\ Senem Şanlı* , Elvan Özsoy', Nurullah Şanlı² \\ 'Department of Chemistry, Faculty of Science and Arts, Uşak University, Uşak, Turkey. \\ 'Department of Food Engineering, Faculty of Engineering, Uşak University, Uşak, Turkey.
}

\section{A B S TR AC T}

\begin{abstract}
A simple, accurate, precise and economical capillary electrophoresis method has been developed for estimation of Sertraline in pharmaceutical dosage form. The estimation of Sertraline was done at $205 \mathrm{~nm}$ in $\mathrm{pH} 4.0$ phosphate buffer. In the developed method, linearity over the concentration range of 1-12 $\mu \mathrm{g} \cdot \mathrm{mL}^{-1}$ of Sertraline was observed. The linear regression was found to be 0.999 . The results of analysis have been validated statistically and recovery studies confirmed the accuracy of the proposed method. The precision (intra-day and inter-day) of method was found within limits (RSD $<2 \%$ ). The sensitivity of the method was assessed by determining limit of detection and limit of quantification. It could be concluded from the results obtained in the present investigation that the method for estimation of Sertraline in pharmaceutical dosage form is simple, rapid, accurate, precise, green and economical, also it could be used, successfully, in the quality control of pharmaceutical formulations and other routine laboratory analysis.
\end{abstract}

\section{Key Words}

Psychiatric illnesses, depression, sertraline, capillary electrophoresis.

\section{öz}

\begin{abstract}
Sertralinin ilaç formülasyonlarından tayini için kolay, seçici, kesin ve ekonomik kapiler elektroforez yöntemi geliştirilmiştir. Tayin 205 nm'de pH'sı 4.0 olan fosfat tamponunda gerçekleştirilmiştir. Geliştirilen yöntemde, doğrusal aralık 1-12 $\mu \mathrm{g} . \mathrm{mL}^{-1}$ arasında bulunmuştur. Korelasyon katsayısı 0.999'dur. Analiz sonuçları istatistiksel olarak valide edilmiş ve geri kazanım çalışmaları yöntemin doğruluğunu onaylamıştır. Yöntemin kesinliği (gün içi ve günler arası) belirlenen sınırlar içerisinde bulunmuştur (RSD < 2\%). Yöntemin duyarlılığı, tayin sınırları belirlenerek değerlendirilmiştir. Bu çalışmada, sertralinin farmasötik dozaj formlarında tayini için basit, hızlı, doğru, hassas, yeşil, ekonomik ve diğer rutin laboratuvar çalışmalarında kullanabilecek bir yöntem geliştirildiği sonucuna varılmıştır.
\end{abstract}

\section{Anahtar Kelimeler}

Psikiyatrik hastalıklar, depresyon, sertralin, kapiler elektroforez.

Article History: Received: Mar 20, 2017; Revised: Jun 04, 2017; Accepted: Sep 12, 2017; Available Online: , 2017.

DOI: 10.15671/HJBC.2018.191

Correspondence to: S. Şanlı, Department of Chemistry, Faculty of Science and Arts, Uşak University, Uşak, Turkey. 


\section{INTRODUCTION}

D epression is one of the most frequent of all major psychiatric illnesses. Major depressions are a common and disabling illness with a lifetime prevalence of $15-20 \%$ [1] Antidepressant medication has been used to treat all forms of major depressive disorder. In spite of some contraindications, these agents are first line treatment when depressions are severe or when there are psychotic and melancholic symptoms [2]. Sertraline (SER) is selective serotonin reuptake inhibitor which is clinically effective for the treatment of depression, obsessive-compulsive disorder, depression relapse and social phobia [3]. It shows the characteristic side effects of the selective serotonin reuptake inhibitors antidepressants and most frequently gastrointestinal disturbances, sexual dysfunctions and anxiety; less frequent are anorexia, urinary retention and orthostatic hypotension. Chemically it is $(1 \mathrm{~S}, 4 \mathrm{~S})-4$ [3,4-dichlorophenyl]-1,2,3,4 tetrahydro-N-methyl1-naphthylamine [4] (Figure 1).

The analytical methods used to monitor sertraline have been reviewed by Bosch et al. [3] and Zhou and Foley [4]. Several methods have been reported for determination of Sertraline such as gas chromatography-mass spectrometric (GC/MS) analysis $[5,6]$, high-performance liquid chromatography (HPLC) coupled with ultra-violet (UV) absorption $[7,8]$, fluorescence $[9,10]$, and MS detection [11,12]. Among these methods, each has disadvantages that limit its application, such as complicated derivatization steps for fluorescence detection, poor sensitivity for UV detection, and expensive equipment for MS detection. Capillary electrophoresis (CE) has become a popular technique for drug analysis because of its high efficiency, rapidity, and small sample volume.

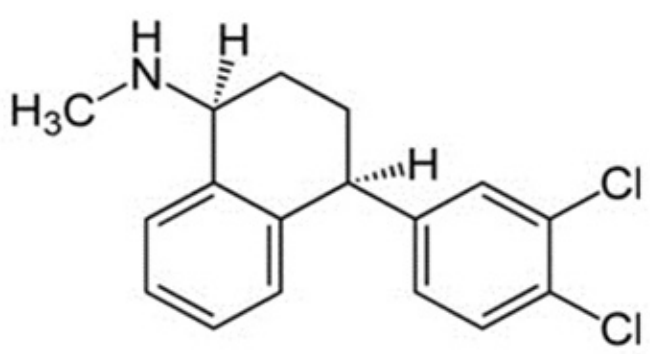

Figure 1. Chemical Structure of Sertraline.
In this paper, we describe a simple, rapid, precise and environmentally friendly capillary electrophoresis method for the simultaneous determination of Sertraline in pharmaceutical dosage form. Citalopram (CIT) was used as an internal standard. The developed method uses no organic solvent in the run buffer and gives baseline separation of the analytes within a $10 \mathrm{~min}$ run time. The method was applied to the analysis of Sertraline in a commercial tablet dosage forms.

\section{MATERIALS and METHODS}

\section{Chemicals}

All chemicals and solvents were of analytical reagent grade and used without further purification. SER and CIT were purchased from Sigma-aldrich. Sodium hydroxide $(\mathrm{NaOH})$, hydrochloric acid $(\mathrm{HCl})$, methanol $(\mathrm{MeOH})$, sodium phosphate, phosphoric acid were of analytical-grade purity and obtained from Sigma-Aldrich (St. Louis MO, USA). Ultrapure water, with conductivity lower than $0.05 \mathrm{~m} /$ $\mathrm{Scm}$ was obtained with a Millipore Direct-Q $3 U \mathrm{~V}$ system (Millipore, Bedford, MA, USA).

Stock standard solutions of SER and CIT were prepared in ultrapure water at $100 \mu \mathrm{g} \cdot \mathrm{mL}^{-1}$. Working solutions were diluted with running buffer to the corresponding $10 \mu \mathrm{g} \cdot \mathrm{mL}^{-1}$. All stock and working solutions were protected from light and stored in fridge at about $4^{\circ} \mathrm{C}$ when not in use. All the solutions that need to go through the capillary have to be first filtered through the $0.25 \mu \mathrm{m}$ membrane and then treated by ultrasound (Bandelin, Sonorex) to remove the air dissolved in the solution.

\section{Apparatus}

The CE analysis was performed on Agilent 7100 Capillary Electrophoresis System (Waldbronn, Germany), equipped with a photodiode array (PDA) detector. Instrument control, peak integrations and peak purity calculations were done by Agilent ChemStation ${ }^{\circledR}$ software. Bare fused silica capillaries were purchased from Agilent Technology. Mettler Toledo Seven multi MA 235 pH/ion analyzer with Mettler Toledo InLab Expert Pro combined glass electrode was used for $\mathrm{pH}$ measurements. The $\mathrm{pH}$ measurements were performed in triplicate to ensure stability and reproducibility of the potentiometric system. 
A $55 \mathrm{~cm} 50 \mu \mathrm{m}$ ID fused silica capillary (Agilent Technologies, U.S.A.) with an effective length of $45 \mathrm{~cm}$ was used for the separation.

\section{Capillary Electrophoresis Procedure}

The separation capillary was activated in the first use by flushing sequentially with $\mathrm{MeOH}$ ( $5 \mathrm{~min}$ ), $1.0 \mathrm{M} \mathrm{HCl}$ (2 min), water (2 min), $1.0 \mathrm{M} \mathrm{NaOH}(20$ $\mathrm{min})$, water (2 $\mathrm{min})$, and then with buffer (20 min). The capillary was conditioned daily by washing with $1.0 \mathrm{M} \mathrm{NaOH}$ (20 min), water (2 min) and finally with the running buffer (20 min). Between each analysis, the capillary was flushed with $1.0 \mathrm{M} \mathrm{NaOH}$ (3 $\mathrm{min}$ ), water ( $2 \mathrm{~min}$ ) and then the running buffer (3 min). Prior to use, buffer solutions were filtered through $0.25 \mu \mathrm{m}$ membrane filters (Millipore Bedford, MA) and degassed by ultrasonication for approximately $10 \mathrm{~min}$. $20 \mathrm{mM}$ phospate buffer was used as background electrolyte (BGE) at $\mathrm{pH}$ 4.0. The capillary cassette temperature was set to $25^{\circ} \mathrm{C}$ during all experiments. The applied voltage was $27 \mathrm{kV}$, hydrodynamic injection was at 100 mbar for $5 \mathrm{~s}$, and the detection was performed at $205 \mathrm{~nm}$ for both drugs.

\section{Analysis of Pharmaceutical Preparations}

Ten tablets of Lustral ${ }^{\circledR}$ (containing 100 mg SER, Pfizer, Turkey), were accurately weighted and powdered. The required amount of this powder, equivalent to a stock solution of $10 \mu \mathrm{g} \mathrm{mL}^{-1} \mathrm{SER}$ was weighted and transferred into a $100 \mathrm{~mL}$ volumetric flask and diluted with ultrapure water. The prepared solution was sonicated for $10 \mathrm{~min}$ to complete dissolution. After filtration, appropriate solutions were prepared by taking suitable aliquots of clear filtrate and adding the appropriate IS solution, diluting them with BGE in order to obtain a final solution. The nominal content of the tablet amounts were calculated from the corresponding regression equations of previously plotted calibration plots from the raw material.

To keep an additional check on the accuracy of the developed assay methods and to study the interference of formulation additives, recovery experiments were carried out. For this purpose, known amount of the pure standard substance of SER, were added the pre-analyzed tablets formulation. After five repeated measurements, the recovery results were calculated by using the related calibration equation for all compounds.

\section{RESULTS and DISCUSSIONS}

\section{Optimization of the Separation Method}

Several compounds were tested as internal standard for using in validation process such as fluoxetine, escitalopram and citalopram. Among these compounds citalopram (CIT) had shorter analysis time, good peak shape and selectivity. CIT (IS) had a maximum absorbance at $205 \mathrm{~nm}$ therefore both compounds could be monitored in $205 \mathrm{~nm}$.

To find out the optimum conditions for electrophoretic separation of drugs, $\mathrm{pH}$ of the run buffer, buffer concentration, applied potential and injection time and pressure parameters were investigated. Several background electrolytes such as borate, tris, phosphate etc. were tested for the CE analysis. Buffer concentration was tested in the concentration range of 5-30 mM phosphate buffer. Higher buffer concentrations cause high current due to Joule heating. It is best to select the minimum buffer concentration with less generated current and efficient separation. Total run time increased with the increase of run buffer concentration. $20 \mathrm{mM}$ phosphate concentration gave the best separation of the drugs. The $\mathrm{pH}$ of the run buffer was investigated in the range of $\mathrm{pH}$ 3.0-5.0. The optimum $\mathrm{pH}$ was determined to be $\mathrm{pH} 4.0$ based on the good resolution, selectivity, and peak shapes of the studied compounds within a relatively short analysis time (10 $\mathrm{min}$ ).

The applied potential was examined in the range of 25, 27, and $29 \mathrm{kV}$. Sharp peaks and less migration time are obtained by increasing the applied voltage. Since the maximum potential is preferred in capillary electrophoresis, $27 \mathrm{kV}$ was applied for the optimum results. The capillary cassette temperature was set to $25^{\circ} \mathrm{C}$. Several injection pressure and time was tested and the longer times and/or the higher pressures caused zone broadening resulting current generation and poor resolution. 100 mbar for 5 seconds were chosen as optimal injection condition. The capillary with total length of $45 \mathrm{~cm}$ was chosen for further analysis due to the shorter capillaries gave shorter migration time. 


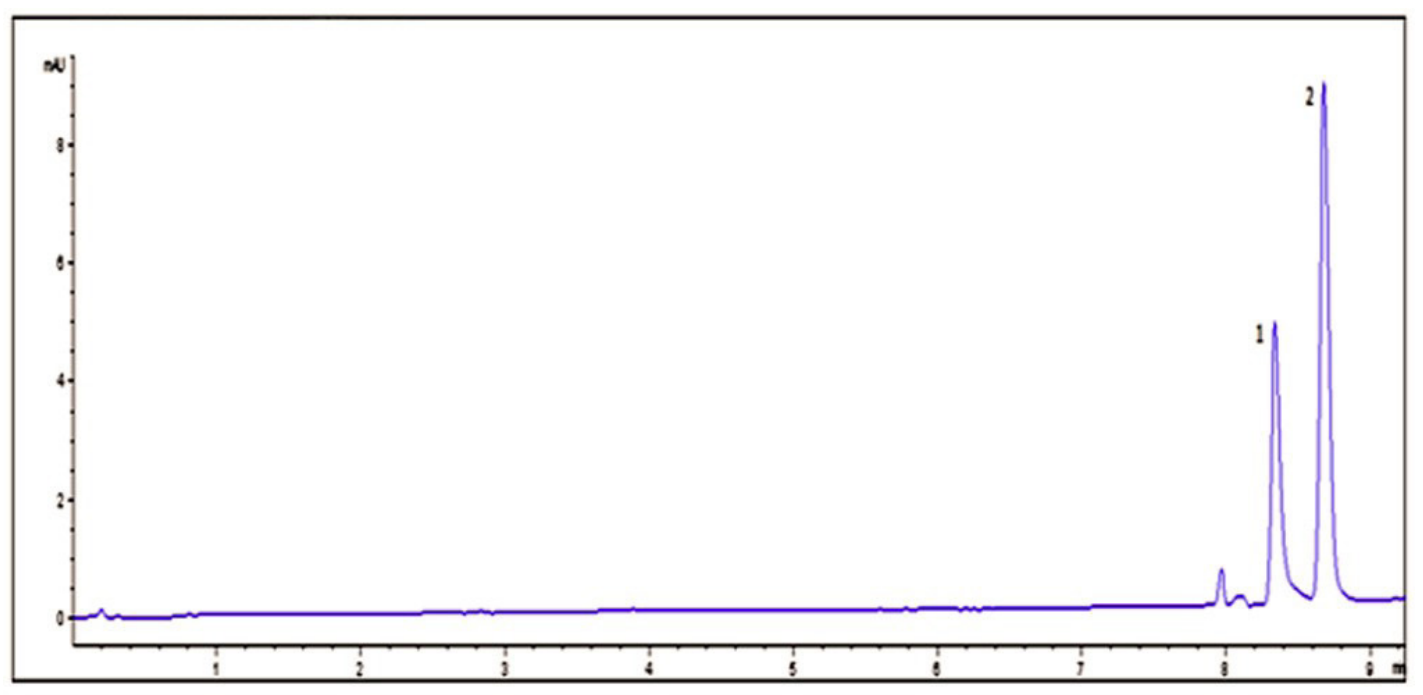

Figure 2. The electropherogram of standard (1) SER and (2) CIT (IS) under optimum conditions.

The optimum separation was obtained with 20 $\mathrm{mM}$ phosphate buffer, $\mathrm{pH} 4.0$, as the run buffer under the applied potential of $27 \mathrm{kV}$ and the standards were injected at 100 mbar pressure for 5 seconds. Under these conditions the migration times were $8.36 \pm 0.04$ and $8.98 \pm 0.07$, minutes for SER and CIT, respectively. An electropherogram of optimum conditions is given in Figure 2 .

The method was validated in accordance with $\mathrm{ICH}$ [13] requirements. The calibration curves were obtained by linear least squares regression. The concentration of IS was maintained at a constant level of $4 \mu \mathrm{g} \cdot \mathrm{mL}^{-1}$ in all validation experiments. The linearity was calculated by plotting the peak area ratio of drug to IS vs. concentration of the compound. Linearity was investigated in the range between 1.00 and $12.00 \mu \mathrm{g} \cdot \mathrm{mL}^{-1}$ for SER and the results were reported in Table 1. The method exhibited good

Table 1. Statistical evaluation of the calibration data of SER by CE.

\begin{tabular}{cc}
\hline & SER \\
\hline Linearity range $\left(\mu \mathrm{g} \cdot \mathrm{mL}^{-1}\right)$ & $\begin{array}{c}1.00-12.00 \\
(\mathrm{n}=5)\end{array}$ \\
\hline Slope & 0.249 \\
\hline Intercept & 0.029 \\
\hline SE of slope & $4.03 .10^{-3}$ \\
\hline SE of intercept & $3.01 .10^{-2}$ \\
\hline $\begin{array}{c}\text { Detection limit }(\mathrm{LOD})\left(\mu \mathrm{g} \cdot \mathrm{mL}^{-1}\right) \\
\text { Quantitation limit }(\mathrm{LOQ})\end{array}$ & 0.9992 \\
$\left(\mu \mathrm{g} \cdot \mathrm{mL}^{-1}\right)$ & 0.0295 \\
\hline
\end{tabular}

linearity based on a correlation coefficient $>0.999$ for compound studied. The LOD and LOQ were

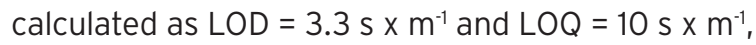
where $s$ is the standard deviation of response and $m$ is the slope of the corresponding calibration curve.

Precision and reproducibility of the method were evaluated by doing replicate analysis of standard solutions containing 2.0-8.0 $\mu \mathrm{g} . \mathrm{mL}^{-1}$ SER and IS was analyzed in consecutive days with five replicates. Repeatability and reproducibility were characterized by mean recovery and RSD and the results are summarized in Table 2 . As can be deduced from Table 2, there was no significant difference for the assay, as tested by within-day (intra-day) and between-days (inter-day). The results supported good precision of the method.

\section{Application of Pharmaceutical Dosage Forms}

The proposed method was successfully applied to tablets containing $8.0 \mathrm{mg}$ SER (Lustral ${ }^{\circledR}$ ). The tablet solutions were prepared as described previously and injected to the system. There was no interference originating from the tablet matrixes and the peaks were carrying the characteristics

Table 2. Summary of repeatability (intra-day) and reproducibility (inter-day) precision data for SER by CE.

\begin{tabular}{|c|c|c|}
\hline Compound & Intra-day & Inter-day \\
\hline $\begin{array}{c}\text { Concentration } \\
\left(\mu \mathrm{g} \cdot \mathrm{mL}^{-1}\right)\end{array}$ & $\begin{array}{c}\text { Mean Recovery* } \\
\% \pm \text { RSD } \%\end{array}$ & $\begin{array}{c}\text { Mean Recovery* } \\
\% \pm \text { RSD } \%\end{array}$ \\
\hline 2.0 & $100.413 \pm 0.727$ & $100.267 \pm 0.591$ \\
\hline 8.0 & $100.094 \pm 0.036$ & $99.908 \pm 0.312$ \\
\hline
\end{tabular}

*Each value is obtained from five experiments $(n=5)$. 


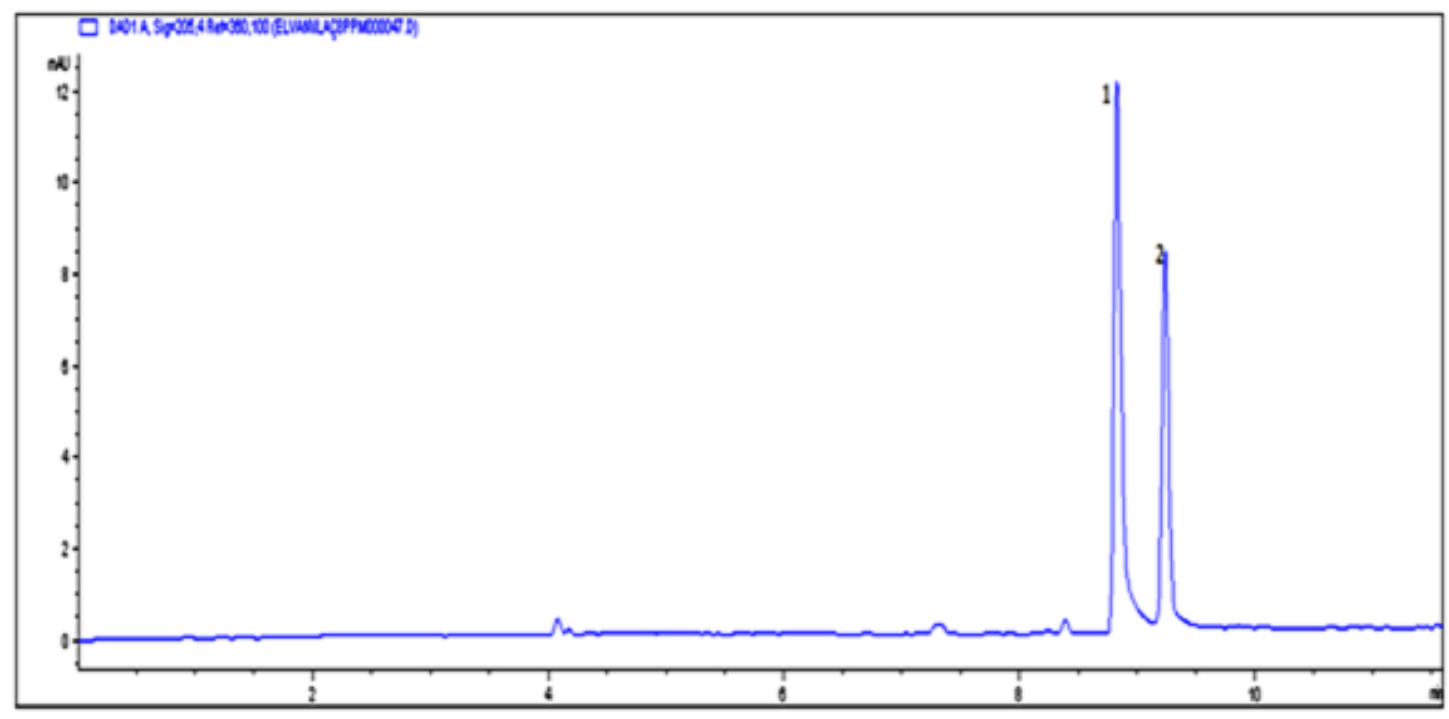

Figure 3. Representative electropherogram obtained from tablet dosage forms Lustral ${ }^{\circledR}$ under optimum conditions, at 205 nm absorbance, (1) SER and (2) CIT (IS).

of standard peaks and electropherogram of tablet samples were given in Figure 3. As shown in Figure 3, the substances were eluted, forming well shaped, symmetrical single peaks, well separated from the solvent front. No interfering peaks were obtained in the electropherogram due to tablet excipients so the removal of the excipients before the analysis was unnecessary. Also assay results obtained are summarized in Table 3 . The utility of the proposed method was verified by means of replicate estimations of pharmaceutical

Table 3. Sertraline assay results and the recovery analysis in pharmaceutical dosage forms.

\begin{tabular}{|c|c|}
\hline & SER \\
\hline Labeled claim (mg) & 8.00 \\
\hline Amount found $(\mathrm{mg})^{\mathrm{a}}$ & \multirow{2}{*}{8.073} \\
\hline RSD (\%) & \\
\hline Bias (\%) & 1.672 \\
\hline Added (mg) & \multirow{2}{*}{-0.913} \\
\hline Found $(\mathrm{mg})^{\mathrm{a}}$ & \\
\hline Recovery (\%) & 4.00 \\
\hline RSD\% of recovery & 4.021 \\
\hline \multirow[t]{3}{*}{ Bias (\%) } & 100.53 \\
\hline & 1.244 \\
\hline & -0.525 \\
\hline
\end{tabular}

preparations and results obtained were evaluated statistically. The quantities found were in conformity with the values claimed by the manufacturer.

\section{CONCLUSIONS}

The present study has demonstrated that a sensitive, simple, rapid, environmentally friendly, experimentally convenient, cost-effective and high-throughput approach for the determination of SER in pharmaceutical dosage forms without the necessity of sample pretreatment, or any time-consuming evaporation or derivatization steps prior to analysis. The amount of studied compounds can be determined within about 10 min after setting to instrument parameters.

The developed CE method might serve as a versatile analytical tool suitable for the assay of SER to the quality control and therapeutic drug monitoring laboratories. Therefore, the method developed here could be used in pharmaceutical preparations and in biological fluids, due to the lower LOD values with short analysis time.

\section{ACKNOWLEDGEMENTS}

This study was supported by Uşak University Scientific Research Projects Commission (BAP) under the grant no: 2015/TP001. 


\section{References}

1. L.L. Judd, Mood disorders in the general population represent an important and worldwide public health problem, Int. Clin. Psychopharmacol., 10 (1995) 5-10.

2. M.J. Burke, S.H. Preskorn, F.E. Bloom, D.J. Kupfer, (eds.), Psychopharmacology: the fourth generation of progress, Raven Press, New York, (1995) 1053.

3. M.E. Bosch, A.J. Ruiz Sanchez, F. Sanchez Rojas, C.B Ojeda, Analytical methodologies for the determination of sertraline, J. Pharm. Biomed. Anal., 48 (2008) 1290-1302.

4. M.X. Zhou, J.P. Foley, Analytical method for the quantitation of sertraline hydrochloride stereoisomers by electrokinetic chromatography, J. Chromatogr. A, 15 (2004) 13-23.

5. A. Khraiwesh, I. Papoutsis, P. Nikolaou, C. Pistos, C. Spiliopoulou, S.J. Athanaselis, Development and validation of an El-GC/MS method for the determination of sertraline and its major metabolite desmethyl-sertraline in blood, J. Chromatogr. B, 879 (2011) 2576-2582.

6. J.P. Lamas, C. Salgado-Petinal, C. Garcia-Jares, M. Llompart, R. Cela, M. Gomez, Solid-phase microextraction-gaschromatography-mass spectrometry for the analysis of selective serotonin reuptake inhibitors in environmental water, J. Chromatogr. A, 1046 (2004) 241-247.

7. L.P. Melo, A.M. Nogueira, F.M. Lancas, M.E.C. Queiroz, Polydimethylsiloxane/polypyrrole stir bar sorptive extraction and liquid chromatography (SBSE/LC-UV) analysis of antidepressants in plasma samples, Anal. Chim. Acta, 633 (2009) 57-64.
8. A.R. Chaves, F.Z. Leandro, J.A. Carris, M.E.C. Queiroz, Microextraction in packed sorbent for analysis of antidepressants in human plasma by liquid chromatography and spectrophotometric detection, J. Chromatogr. B, 878 (2010) 2123-2129.

9. G. Bahrami, B. Mohammadi, A. Farshchi, G. Ghiasi, Quantitative analysis of sertraline in human serum by LC with fluorescence detection after pre-column derivatization with 4-chloro-7-nitrobenzofurazan, Chromatographia, 70 (2009) 323-327.

10. N.Y. Khalil, A.M. Mahmoud, I.A. Darwish, A.A. Al-Majed, Highly sensitive LC method with automated co-sense system and fluorescence detection for determination of sertraline in human plasma, Chromatographia, 71 (2010) 825-831.

11. M.M. Zheng, S.T. Wang, W.K. Hu, Y.Q. Feng, Intube solid-phase microextraction based on hybrid silica monolith coupled to liquid chromatographymass spectrometry for automated analysis of ten antidepressants in human urine and plasma, J. Chromatogr. A, 1217 (2010) 7493-7501.

12. J.M. Conley, S.J. Symes, S.A. Kindelberger, S.M. Richards, Rapid liquid chromatography-tandem mass spectrometry method for the determination of a broad mixture of pharmaceuticals in surface water, J. Chromatogr. A, 1185 (2008) 206-215.

13. Guideline, ICH Harmonized Tripartite, Validation of analytical procedures: text and methodology, Q2 (R1) 2005; Available from URL: http://www.ich. org/products/guidelines/quality/article/qualityguidelines.html 